\title{
PENGARUH PENGGUNAAN WEBTOON TERHADAP KETERAMPILAN MENULIS PANTUN
}

\author{
Nuratikah $^{1)^{*}}$, Aida Sumardi ${ }^{2)}$ \\ Program Studi Pendidikan Bahasa dan Sastra Indonesia, Fakultas Ilmu Pendidikan, \\ Universitas Muhammadiyah Jakarta \\ hola.atika@gmail.com, aida.sumardi@umj.ac.id
}

\begin{abstract}
ABSTRAK
Penelitian ini dilatarbelakangi oleh minimnya hasil belajar siswa pada pelajaran bahasa Indonesia terutama pada keterampilan menulis pantun. Tujuan penelitian ini adalah untuk melihat pengaruh Webtoon terhadap keterampilan menulis pantun. Metode yang digunakan adalah True Experimental Design dengan Posttest-Only Control Design, dengan hipotesis terdapat pengaruh penggunaan Webtoon terhadap keterampilan menulis pantun di kelas VII SMP Islam Ruhama Ciputat. Hasil penelitian ini menunjukkan bahwa terdapat pengaruh yang signifikan penggunaan Webtoon terhadap keterampilan menulis pantun siswa kelas VII SMP Islam Ruhama Ciputat. Hal ini terbukti dari hasil perhitungan thitung sebesar 5, 732 lebih besar dari pada $t_{\text {tabel }}$ sebesar 2,00856. Dengan demikian dapat disimpulkan bahwa penggunaan Webtoon memberikan pengaruh terhadap keterampilan menulis pantun siswa kelas VII SMP Islam Ruhama Ciputat. Hasil penelitian ini diharapkan dapat bermanfaat kepada pihak-pihak terkait seperti kepala sekolah, guru, siswa, dan peneliti selanjutnya.
\end{abstract}

Kata kunci: Webtoon, menulis pantun, hasil belajar

\section{PENDAHULUAN}

$\mathbf{K}$ eterampilan berbahasa terdiri atas empat aspek yang berkesinambungan antara satu dengan yang lainnya. Empat keterampilan tersebut adalah keterampilan menyimak yang pertama kali dimiliki oleh manusia sejak lahir, keterampilan berbicara adalah keterampilan kedua yang dikuasai manusia yang digunakan untuk menyampaikan sebuah pesan secara langsung (ujaran), keterampilan menulis, dan membaca saling berkesinambungan antara satu dengan yang lainnya. Menulis dianggap sebagai keterampilan yang paling sulit. Materi mengenai menulis pantun merupakan pelajaran Bahasa Indonesia yang terdapat di kelas VII. 
Nama Penulis : Judul Artikel

Website : https://jurnal.umj.ac.id/index.php/penaliterasiEmail : penaliterasi@umj.ac.id

Menurut Liang Gie dalam Saleh (2013:27) menulis adalah keseluruhan rangkaian kegiatan seseorang dalam mengungkapkan gagasan dan menyampaikan bahasa tulis kepada pembaca untuk dipahami dan dimengerti oleh orang lain. Sedangkan menurut Dalman (2008:18) menulis merupakan suatu kegiatan komunikasi berupa penyampaian pesan (informasi) secara tertulis kepada pihak lain dengan menggunakan bahasa tulis sebagai alat atau medianya. Pada pembelajaran Bahasa Indonesia di Sekolah Menengah Pertama, materi menulis pantun terdapat pada Kompetensi Dasar (KD) 3.9 dan 4.9. dalam menulis pantun ada beberapa hal yang harus diperhatikan seperti tiap bait harus terdiri dari empat baris, bersajak a-b-a-b, baris pertama dan kedua berisi sampiran dan baris kedua berisi isi pantun tersebut (Damayanti, 2013: 115).

Menulis pantun merupakan salah satu materi yang dianggap rumit oleh siswa, hal ini dikarenakan siswa mengalami kesulitan dalam menyamakan sajak pada tiap akhir kalimat. Selain itu, siswa juga tidak mempunyai inspirasi yang memadai dalam membuat pantun. Hal ini membuat hasil belajar siswa tentang menulis pantun belum mencapai target atau di bawah Kriteria Ketuntasan Minimal (KKM).
Masalah yang dijelaskan di atas merupakan hasil wawancara dan observasi di SMP Islam Ruhama Ciputat. Hal ini makin diperparah dengan penggunaan media pembelajaran yang seadanya dan monoton. Guru mata pelajaran masih menggunakan teknik konvensional dalam menyampaikan materi pembelajaran kepada siswa.

Berdasarkan masalah yang telah dijelaskan di atas, penelti tertarik untuk melakukan penelitian pada siswa di SMP Islam Ruhama Ciputat dengan menggunakan Webtoon sebagai media penunjang dalam menulis pantun. Menurut Seung (2013: 984) istilah Webtoon digunakan untuk membedakan dari buku komik yang diterbitkan sebagai tujuan Webtoon diciptakan untuk dilihat di web. Namun, setelah munculnya smart media, konsep dari Webtoon telah meluas dan didefinisikan sebagai barang kreatif yang dikombinasikan dengan cerita, gambar, dan teknik. Sedangkan menurut kamus Oxford, Webtoon is Ananimated cartoon or series of comic strips published online. Artinya Webtoon adalah sebuah kartun animasi atau serangkaian strip komik yang diterbitkan secara online.

Penggunaan Webtoon dalam pembelajaran menulis pantun diharapkan dapat membuat suasana belajar yang lebih menarik dan menyenangkan. Selain itu, penggunaan Webtoon juga diharapkan bias 
merangsang kreativitas siswa dalam membuat pantun.

Berdasarkan latar belakang masalah di atas, peneliti terdorong untuk melakukan penelitian dengan jduul Pengaruh Penggunaan Webtoon terhadap Keterampilan Menulis Pantun.

\section{METODE PENELITIAN}

Puelitian ini dilakukan di SMP Islam
Ruhama Ciputat dengan menggunakan metode kuantitatif dan menerapkan metode eksperimen. Penelitian eksperimen digunakan untuk mencari pengaruh perlakuan tertentu terhadap yang lain dalam kondisi yang terkendalikan (Sugiyono, 2016: 72). Selain itu, desain yang digunakan adalah ekperimen yang digunakan yakni true experiment desain dengan menggunakan rancangan Posttest Only Control Design. Dalam penelitian ini terdapat dua kelas yang ditetapkan sebagai kelas kontrol dan kelas eksperimen. Kelas kontrol tidak diberikan treatment yaitu masih menggunakan metode pembelajaran seperti sebelumnya, sementara kelas eksperimen diberikan treatment yaitu berupa Webtoon untuk melihat pengaruhnya. Kelas kontrol dan kelas eksperimen dipilih secara acak dengan simple random sampling.

Adapun hasilnya didapatkan kelas VII. 1 sebagai kelas eksperimen dan kelas VII.2 sebagai kelas kontrol.
Populasi dalam penelitian ini adalah seluruh siswa kelas VII SMP Islam Ruhama Ciputat. Sementara untuk sampelnya adalah seluruh siswa kelas VII.1 yang terpilih sebagai kelas eksperimen dan seluruh siswa kelas VII.2 yang terpilih sebagai kelas kontrol. Adapun jumlah siswa di kelas VII. 1 (eksperimen) sebanyak 24 orang dan kelas VII.2 (kontrol) sebanyak 26 orang.

Teknik pengumpulan data dalam penelitian ini menggunakan beberapa metode yaitu uji validitas instrumen, dokumentasi dan metode tes. Pada uji validitas instumen, peneliti menggunakan uji valididtas kontruk (judgement expert). Adapun hasil dari uji validitas tersebut ahli memberikan beberapa saran yaitu peambahan jumlah soal menjadi sepuluh soal dan sistem penilaian tes.

Setelah memperoleh data dari sampel terkumpul, langkah selanjutnya adalah menganalisis data. Pada penelitian ini analiis data dilakukan dengan menggunakan statistik. Adapun teknik analisis data yang digunakan adalah uji normalitas, uji homogenitas, dan uji hipotesis. Uji hipotesis dilakukan untuk mengetahui apakah penggunaan Webtoon berpengaruh terhadap keterampilan menulis pantun pada siswa kelas VII SMP Islam Ruhama Ciputat. 


\section{HASIL DAN PEMBAHASAN}

ada penelitian ini terdapat dua kelas
yang berperan sebagai kelas ekperimen dan kelas kontrol. Penelitian ini dilakukan sebanyak dua kali pertemuan pada tiap kelasnya. Pada pertemuan pertama di kelas kontrol, peneliti menjelaskan materi mengenai pantun dan cara menulis pantun. Hal demikian juga dilakukan terhadap kelas eksperimen. Pada pertemuan pertama, tidak ada perbedaan perlakuan antara kelas ekperimen dan kelas kontrol. Selanjutnya, pada pertemuan kedua di kelas kontrol peneliti memberikan tes yang berupa pertanyaan mengenai pantun dan menulis pantun, di kelas ini siswa diberikan cerpen sebagai media pembantu dalam menulis pantun. Sementara pada kelas eksperimen, peneliti memberikan tes berupa beberapa pertanyaan mengenai pantun dan menulis pantun, siswa kelas eksperimen diberikan media berupa Webtoon untuk membantu siswa dalam menulis pantun.

\section{Deskripsi Data Kelas Eksperimen}

Setelah memberikan tes pada kelas eksperimen, langkah selanjutnya adalah melakukan penilaian pada hasil tes tersebut. hasil tes didapatkan dari perhitungan penskoran yang sudah disusun oleh peneliti. Adapun hasil tes tersebut akan diolah melalui SPSS versi 22 untuk menentukan mean, median, modus, standar deviasi, rentang, nilai maksimun, nilai minimum dan varian.

Berdasarkan hasil tes tersebut didapatkan perolehan nilai terendah adalah 65 dan nilai tertinggi adalah 100. Selain itu terdapat 12 orang siswa mendapatkan nilai 100, 4 orang siswa mendapatkan nilai 95, 3 orang siswa mendapatkan nilai 85,2 orang siswa mendapatkan nilai 80,1 orang siswa mendapatkan nilai 75,1 orang siswa mendapatkan nilai 70 dan 1 orang siswa mendapatkan nilai 65. Adapun mean atau nilai rata-rata pada kelas eksperimen sebesar 89,20, median atau nilai tengah sebesar 95, modus sebesar 100, standar deviasi sebesar 13,66, varian sebesar 186,83, dan rentang sebesar 50.

\section{Deskripsi Data Kelas Kontrol}

Setelah memberikan tes pada kelas kontrol, langkah selanjutnya adalah melakukan penilaian pada hasil tes tersebut. hasil tes didapatkan dari perhitungan penskoran yang sudah disusun oleh peneliti.

Adapun hasil tes tersebut akan diolah melalui SPSS versi 22 untuk menentukan mean, median, modus, standar deviasi, rentang, nilai maksimun, nilai minimum dan varian.

Adapun hasil yang diperoleh pada kelas kontrol VII.2 adalah terdapat 3 orang siswa mendapat nilai 40,1 orang siswa 
mendapat nilai 45,4 orang siswa mendapat nilai 50, 1 orang siswa mendapat nilai 55, 3 orang siswa mendapat nilai 60,1 orang siswa mendapat nilai 65,1 orang siswa mendapat nilai 70,1 orang siswa mendapat nilai 75,3 orang mendapat nilai 80,6 orang siswa mendapat nilai 85 dan 2 orang siswa mendapat nilai 90. Nilai terendah pada kelas kontrol adalah 40 dan nilai tertinggi adalah 90 .

Adapun mean atau nilai rata-rata pada kelas kontrol sebesar 67, median atau nilai tengah sebesar 67,5, modus sebesar 85, standar deviasi sebesar 17,59, varian sebesar 309,5, dan rentang sebesar 50.

Dari kedua data yang telah dijabarkan di atas yaitu data kelas eksperimen maupun data kelas kontrol, dapat disimpulkan bahwa perolehan nilai keterampilan menulis teks pantun pada kelas eksperimen lebih baik daripada perolehan nilai keterampilan menulis pantun pada kelas kontrol. Perbandingan keduanya dapat dilihat dari tabel statistik berikut.

Tabel 1.

Perbandingan Data

Statistik Hasil Penelitian

\begin{tabular}{|c|c|c|}
\hline \multirow{2}{*}{ Statistik } & \multicolumn{2}{|c|}{ Kelas } \\
\cline { 2 - 3 } & Eksperimen & Kontrol \\
\hline Nilai & 65 & 40 \\
\hline
\end{tabular}

\begin{tabular}{|c|c|c|}
\hline terendah & & \\
\hline $\begin{array}{c}\text { Nilai } \\
\text { tertinggi }\end{array}$ & 100 & 90 \\
\hline Mean & 89,2 & 67 \\
\hline Modus & 100 & 85 \\
\hline
\end{tabular}

Berdasarkan table di atas dapat disimpulan bahwa terdapat perbedaan yang signifikan pada nilai rata-rata antara kelas eksperimen dan kelas kontrol. Kelas kontrol memperoleh nilai rata-rata sebesar 67 sedangkan kelas ekperimen memperoleh nilai rata-rata sebesar 89,2 . Selisih dari nilai kedua kelompok tersebut yaitu 22,2. Hal tersebut menunjukkan bahwa hasil belajar keterampilan menulis pantun pada kelas eksperimen dengan menggunakan Webtoon lebih baik dibandingkan dengan hasil belajar keterampilan menulis pantun kelas kontrol dengan tidak menggunakan Webtoon.

\section{Hasil Uji Hipotesis}

Berdasarkan hasil uji $t$ dengan menggunakan independent sample test pada tabel didapatkan nilai $t$ hitung sebesar 5,732 dengan nilai $t_{\text {tabel }}$ sebesar 2,008. Maka dapat dinyatakan bahwa Ho ditolak dan $\mathrm{Ha}$ diterima. Hal ini juga menunjukkan bahwa rata-rata keterampilan menulis pantun siswa yang diterapkan penggunaan Webtoon lebih 
Nama Penulis : Judul Artikel

Website : https://jurnal.umj.ac.id/index.php/penaliterasiEmail : penaliterasi@umj.ac.id

tinggi dibandingkan rata-rata keterampilan menulis pantun siswa yang menggunakan metode pembelajaran konvensional. Dengan demikian dapat dikatakan bahwa terdapat pengaruh dari penggunaan Webtoon terhadap keterampilan menulis pantun siswa kelas VII SMP Islam Ruhama Ciputat.

\section{Interpretasi Hasil Penelitian}

Penelitian ini bertujuan untuk mengetahui apakah terdapat pengaruh penggunaan Webtoon terhadap kemampuan menulis pantun pada mata mata pelajaran Bahasa Indonesia di SMP Islam Ruhama Ciputat. Penelitian ini dilakukan terhadap dua kelas yang bertindak sebagai kelas eksperimen dan kelas kontrol. Pengambilan sampel dalam penelitian ini menggunakan teknik random sampling. Selain itu, data dikumpulkan menggunakan teknik pengumpulan data yaitu PosttestOnly Control Design. Setelah mendapatkan data dari soal yang telah diujikan pada siswa, peneliti melakukan analisis data.

Penelitian ini dilakukan sebanyak dua kali pertemuan pada tiap kelas. Proses pembelajaran pada pertemuan pertama di kelas eksperimen dan kelas kontrol sama, tidak ada perbedaan perlakukan atau treatment yang diberikan. Selanjutnya pada pertemuan kedua peneliti memberikan refleksi dari materi yang sudah dipelajari pada pertemuan sebelumnya, setelah itu siswa pada kelas eksperimen diminta untuk mengisi serangkaian soal mengenai pantun dengan bantun media Webtoon, sedangkan di kelas kontrol siswa diminta mengisi soal mengenai pantun namun tidak menggunakan bantuan media berupa Webtoon dengan tema Ibu.

Pada saat proses pembelajaran berlangsung, siswa kelas VII.1 sebagai kelas eksperimen lebih bersemangat dalam belajar, hal ini dikarenakan peneliti memperkenalkan media baru yaitu Webtoon. Hampir seluruh siswa kelas eksperimen memiliki akun Webtoon, mereka senang membaca cerita-cerita yang terdapat dalam Webtoon tersebut. Selain itu, pada saat dilakukan tes kelas eksperimen dapat mengisi dengan mudah pertanyaanpertanyaan yang diajukan. Hal ini disebabkan oleh kalimat-kalimat yang terdapat pada Webtoon cenderung singkat, padat dan jelas.

Selain itu, media Webtoon juga menarik karena menggunakan percakapan antar tokoh dan tiap tokoh yang terdapat dalam cerita digambarkan secara menarik melalui penampilan seperti penggunaan pakaian dan pemilihan warna dalam penyajian Webtoon. Penggunaan kata yang sesuai dengan siswa terlihatdalam Webtoon Ngopi Yuk! Episode Ibu seperti kata IG (instagram), up to dates, guys, dan lain 
sebagainya. Selain itu, juga ditemukan penggunaan kata 'gawai' yang merupakan kata yang belum terlalu familiar di telinga masyarakat Indonesia.

Hal ini menunjukkan bahwa WebtoonNgopi Yuk! Episode Ibu memiliki kelebihan dalam penyajian cerita. Sehingga membuat siswa mudah mengerti maksud atau cerita yang disampaikan di dalam Webtoon tersebut.

Berbeda dengan kelas VII.2 sebagai kelas eksperimen, siswa tampak bisaa saja dan tidak begitu memperhatikan ketika dijelaskan mengenai pelajaran. Beberapa siswa terlihat mengobrol dan bercanda dengan temannya. Selain itu, pada saat diberikan tes siswa cenderung lamban dalam menemukan maksud atau tujuan cerita yang disajikan. Hal ini dikarenakan kalimat yang terlalu panjang sehingga siswa kesulitan menemukan maksud atau tujuan dari cerita yang mereka baca. Hal lain yang membuat siswa bosan membaca cerita yang disajikan adalah tidak adanya gambar pada cerita tersebut.

Berbeda dengan Webtoon yang menyajikan kalimat dalam bentuk yang singkat, padat dan jelas, selain itu Webtoon juga menampilkan gambar percakapan tiap tokoh yang didesain semenarik mungkin, sehingga siswa mudah menemukan maksud atau tujuan dari cerita tersebut dan tidak merasa bosan ketika membaca sebuah cerita.

Berdasarkan hasil analisis data yang telah dilakukan peneliti, diketahui bahwa terdapat pengaruh penggunaan Webtoon terhadap kemampuan menulis pantun pada kelas eksperimen. Perbedaan hasil dari kelas eksperimen dan kelas kontrol terlihat dari nilai terendah pada kelas eksperimen adalah 65 dan tertinggi adalah 100, sementara di kelas kontrol nilai terendah adalah 40 dan nilai tertinggi adalah 90 . Maka dari itu, dapat disimpulkan bahwa nilai rata-rata kelas eksperimen lebih besar daripada kelas kontrol.

Pada penelitian ini, soal yang berkaitan langsung dengan penggunaan Webtoonterhadap menulis pantun terdapat pada soal nomor 5 dan 6. Pada kelas eksperimen nilai rata-rata siswa pada soal nomor 5 adalah 9,79 dan pada soal nomor 6 nilai rata-rata siswa adalah 100 . Sementara kelas kontrol nilai rata-rata siswa pada soal nomor 5 adalah 8,65 dan pada soal nomor 6 nilai rata-rata siswa adalah 5,57 . Hal ini membuktikan terdapat pengaruh yang signifikan terhadap kemampuan menulis pantun dengan menggunakan Webtoon.

Berdasarkah hasil penelitian dan analisis data, hipotetsis membuktikan bahwa Ho ditolak dan $\mathrm{Ha}$ diterima, hal ini menunjukkan bahwa kemampuan menulis 
Nama Penulis : Judul Artikel

Website : https://jurnal.umj.ac.id/index.php/penaliterasiEmail : penaliterasi@umj.ac.id

pantun di kelas eksperimen menggunakan

Webtoon sebagai media pembelajaran lebih baik daripada kemampuan menulis pantun di kelas kontrol tanpa menggunakan Webtoon sebagai media pembelajaran. Maka dapat disimpulkan bahwa, menulis pantun dengan menggunakan Webtoon dapat memberikan pengaruh yang baik.

\section{KESIMPULAN}

$\mathbf{B}_{\text {diuraikan di atas, maka dapat }}^{\text {erdasarkan hasil penelitian yang telah }}$ disimpulkan bahwa terdapat pengaruh penggunaan Webtoon terhadap keterampilan menulis pantun pada siswa kelas VII SMP islam Ruhama Ciputat. Adapun hasil penelitian dapat disimpulkan secara khusus sebagai berikut.

1. Penggunaan Webtoon pada siswa kelas VII SMP Islam Ruhama cukup baik. Banyak siswa yang sudah menggunakan aplikasi Webtoon, akan tetapi selama ini Webtoon belum pernah dijadikan sebagai media pembelajaran.

2. Setelah melakukan penelitian ini, penelitian mengetahui bahwa terdapat pengaruh penggunaan webtoon terhadap keterampilan menulis pantun pada siswa kelas VII SMP Islam Ruhama Ciputat khususnya kelas eksperimen. Nilai siswa yang menggunalkan Webtoon dalam menulis pantun lebih besar dibandingkan dengan siswa yang tidak menggunakan Webtoon dalam menulis pantun.

\section{UCAPAN TERIMA KASIH}

ada kesempatan ini, peneliti ingin
mengucapkan banyak terima kasih kepada semua pihak yang telah turut serta membantu terselesaikannya penelitian ini. Peneliti mengucapkan terima kasih kepada Universitas Muhammadiyah Jakarta yang menjadi tempat peneliti bernaung dalam mengembangkan ilmu pengetahuan dan pendidikan.

\section{REFERENSI}

Dalman. 2016. Keterampilan Menulis. Jakarta: PT Raja Grafindo Persada.

Damayanti, D. 2013. Buku Pintar Sastra Indonesia. Yogyakarta: Araska.

Oxford Dictionary,"Definition of Webtoon in English" (online) http://en.oxforddictionaries.com/def inition/webtoon diakses tanggal $05 / 12 / 2018$

Saleh, Zuleha. 2013. Terampil Menulis Di Sekolah Dasar. Tangerang: Pustaka Mandiri. 
PENA LITERASI : Jurnal PBSI

Volume 1 No. 2 Bulan Oktober Tahun 2018

Seung, Jin Lee. 2013. A Study on Strategic

Modeling to Develop Comics

Content with Smart Device Platform

Volume $\quad 7, \quad$ NO.6(online)

http://dx.doi.org/10.14257/ijsh.2013

7.6.01diakses pada 2/12/2018

Sugiyono. 2016. Metode Penelitian

Pendidikan. Bandung: Alfabeta 